University of Pennsylvania Carey Law School

Penn Law: Legal Scholarship Repository

Faculty Scholarship at Penn Law

5-7-2018

\title{
The Ethics of Medicaid's Work Requirements and Other Personal Responsibility Policies
}

Harald Schmidt

University of Pennsylvania Perelman School of Medicine

Allison K. Hoffman

University of Pennsylvania Carey Law School

Follow this and additional works at: https://scholarship.law.upenn.edu/faculty_scholarship

Part of the Administrative Law Commons, Ethics and Political Philosophy Commons, Health Economics Commons, Health Law and Policy Commons, Health Policy Commons, Inequality and

Stratification Commons, Law and Society Commons, Medicine and Health Commons, Policy Design, Analysis, and Evaluation Commons, Social Policy Commons, Social Welfare Commons, and the Social Welfare Law Commons

\section{Repository Citation}

Schmidt, Harald and Hoffman, Allison K., "The Ethics of Medicaid's Work Requirements and Other Personal Responsibility Policies" (2018). Faculty Scholarship at Penn Law. 2207.

https://scholarship.law.upenn.edu/faculty_scholarship/2207

This Article is brought to you for free and open access by Penn Law: Legal Scholarship Repository. It has been accepted for inclusion in Faculty Scholarship at Penn Law by an authorized administrator of Penn Law: Legal Scholarship Repository. For more information, please contact PennlawIR@law.upenn.edu. 


\title{
The Ethics of Medicaid's Work Requirements and other Personal Responsibility Policies
}

For final version, please see https://jamanetwork.com/journals/jama/article$\underline{\text { abstract } / 2681081}$

Harald Schmidt, PhD

Assistant Professor, Department of Medical Ethics and Health Policy

Research Associate, Center for Health Incentives and Behavioral Economics

Perelman School of Medicine, University of Pennsylvania

Senior Fellow, Leonard Davis Institute

Blockley Hall, 1410, 423 Guardian Drive

Philadelphia, PA 19104

T: 215-573-4519, E: schmidth@mail.med.upenn.edu

$\mathrm{W}: \underline{\text { http://medicalethicshealthpolicy.med.upenn.edu/faculty-all/harald-schmidt }}$

\author{
Allison K Hoffman, JD \\ Professor of Law \\ University of Pennsylvania Law School \\ Senior Fellow, Leonard Davis Institute \\ 3501 Sansom Street, Philadelphia, PA 19104 \\ T: 215.898.7483, E: ahoffman@law.upenn.edu \\ W: https://www.law.upenn.edu/cf/faculty/ahoffmal/
}

- 1375 words - 
DRAFT Work in Progress 
Breaking controversial new ground, the Centers for Medicare \& Medicaid Services (CMS) recently invited states to consider establishing work requirements as a condition of receiving Medicaid benefits. Non-compliant beneficiaries may lose some or all of their benefits and, if they do, will incur higher spending if they have to pay for medical care out-of-pocket. Current evidence suggests work requirements and related policies, which proponents claim promote personal responsibility, can create considerable risks of health and financial harm in vulnerable populations. ${ }^{1,2,3}$ Concerns about implementing these policies in Medicaid at all have been widely expressed, including by major physician organizations, 4 and others have examined their legality. ${ }^{4} 5$ Setting these important issues aside, if the policies survive legal challenges, CMS should act to minimize harms to the health of Medicaid's vulnerable population that could result from them. To this end, CMS should create guidance that would minimize risks, ensure proportionality of penalties (i.e., that benefits are not cut for first-time or relatively minor infractions), and stipulate when harms rise to a level that requires program changes or termination.

Federal guidelines establish which populations and benefits states must cover under Medicaid. Section 1115 waivers permit states to propose demonstration projects to test alternative program designs. In Fall 2017, CMS issued a Bulletin "ushering in a new era" for waivers.5 Specifically, CMS invited proposals encouraging "personal responsibility," in the form of incentives for beneficiaries to use fewer services and to transition to private insurance.

In January 2018, a subsequent CMS letter to state Medicaid directors set out guidelines for the new era. The letter encourages testing work requirements or community engagement—such as job skills training or public service - as a condition of eligibility, coverage, enhanced benefits, or reduced premiums or cost-sharing. Applying to beneficiaries who are not pregnant, elderly, or disabled, CMS claims programs will "promote better mental, physical, and emotional health" and "help individuals and families rise out of poverty and attain independence."6 Recently, CMS approved applications from Kentucky, Indiana and Arkansas, and applications from other states are pending. 
CMS emphasizes health improvement as the primary rationale, but the agency and interested states also favor work requirements for their potential to limit enrollment and spending and out of an ideological belief that everyone 'do their part.' For example, an Executive Order by Kentucky's Governor Matt Bevin announced that the state's entire Medicaid expansion would be unaffordable if the waiver were not implemented, threatening to end expansion if courts strike down "one or more" ${ }^{\sharp 6}$ program elements. Correspondingly, several non-expansion states have signaled that the option of introducing work requirements might make them reconsider expansion-potentially covering more people but arguably in a way inconsistent with Medicaid's broader objectives. ${ }^{5}$

Work requirements have attracted the most attention but are just one of many policies CMS has encouraged as part of apparent attempts to promote personal responsibility in Medicaid. Other initiatives tie levels of benefits to confirming eligibility annually, paying premiums on time, meeting wellness program criteria such as completing health risk assessments, or not using the emergency department (ED) for nonemergency care. 8

Prior demonstrations of personal responsibility policies have produced heterogeneous outcomes, raising concerns regarding both their ethics and effectiveness. For example, a West Virginia Medicaid demonstration project under the Deficit Reduction Act of 2005 required participants to agree to certain behaviors, including completing a health-improvement plan, avoiding the ED for nonemergency care, and engaging in health-conducive behaviors. Compliance with these behaviors enabled access to all previously available services. Non-compliance resulted in access to a reduced set of benefits. The program decreased ED visits for some beneficiaries, but, overall, resulted in an increase of about $10 \%$ in avoidable ED visits. ${ }^{1}$

Medicaid beneficiaries in states that implement work requirements who lose access to previously-available medical benefits are at risk. One study, reviewing a decade of research, reported that insurance coverage losses "produce significant harms to health, particularly among people with lower incomes and chronic conditions."2 Even though CMS exempts some groups from work requirements, evidence suggests some non-exempted Medicaid beneficiaries encounter major challenges. For Kentucky, it is estimated that nearly $50 \%$ of a total of around 
653,000 non-elderly adults in Medicaid will be exempt.3 Another 26\% (169,000 enrollees) already work, but one-third of this group may not consistently meet the program's 20 hour per week threshold due to contingent work, in which hours vary by week or season.3 Twenty-eight percent of nonelderly adults, approximately 188,000 individuals, are not exempt and do not already work. 3 Yet, among this population, $41 \%$ have one or more serious health limitations, and almost a quarter two or more such impariments. 3 These include $21 \%$ with cognitive limitations (serious difficulty concentrating, remembering, or making decisions), $26 \%$ with ambulatory limitation (serious problems walking, climbing stairs) and $18 \%$ with serious difficulties running errands. 3 One-quarter have no high school degree and $12 \%$ have no access to a vehicle. 3 It is reasonable to assume that people with such limitations will struggle to comply with the new requirements.

It is troubling that these policies could result in some portion of previously eligible individuals being denied necessary medical care because of unduly demanding requirements. Ironically, lack of access to medical benefits may make it harder for them to be able to work in the future. Moreover, even if reduced enrollment were to decrease Medicaid cost, it might not reduce medical spending overall. Laws including the Emergency Medical Treatment and Labor Act still require stabilization of emergency medical conditions, entailing more expensive and less effective care.

Considering the risk of harm, CMS should put strong risk protections in place. Legally, for more than 3 decades, demonstrations have been exempt from the Common Rule governing research. Practically, however, work requirements, and other personal responsibility demonstrations that jeopardize Medicaid access, are research involving vulnerable populations and should be paired with similar protections.

CMS should provide guidance to minimize health risks, protect beneficiaries from penalties disproportional to their level of noncompliance, and to clarify when harms require a state to modify or end a demonstration project. Some basic safeguards can offer first steps in this direction. 
First, CMS and states should continuously evaluate the feasibility of meeting new conditions. Proponents emphasize that programs include alternatives to work requirements (in Kentucky: seven types of job training or community service activities). ${ }^{5-8}$ Offering a range of options might seem accommodating, but the available evidence suggests that it may not be sufficient for Medicaid beneficiaries who face complex and challenging circumstances. Before they suspend or terminate beneficiaries from Medicaid, CMS and states should seek to understand why they have failed, and implement support systems to help them. CMS should also offer guidance on proportionality of noncompliance and penalties. For example, it would be disproportionate to cut Medicaid access for someone whose work typically meets hours requirements but falls short for one month because of the variable nature of her work, or who arrives to work late on occasion. CMS should therefore offer additional clarification to avoid beneficiaries losing benefits for relatively minor violations.

Second, especially high-risk subgroups, who can be identified through Medicaid utilization data, should receive proactive case-worker support by default, or should be exempted altogether from the requirements.

Third, when beneficiaries have periods of suspended eligibility due to failure to meet requirements, physicians should be able and expected to request exemptions to continue to provide critical medical care. The formal evaluation of the West Virginia program suggested that even minor barriers to requesting such exemptions caused physicians to forgo providing necessary care, shifting patients to using ED care. ${ }^{1}$

Fourth, states should monitor the long-term health effects resulting from absent or delayed care when individuals lose coverage due to failure to meet requirements and later present in the ED. CMS should offer guidance on what level of harm triggers program adjustment or termination.

Fifth, CMS should ensure the utmost procedural openness and transparency. All waiver applications and evaluations should be publicly accessible on a central website, mirroring clinical trials policy, where clinicaltrials.gov has considerably improved transparency. Central, comprehensive information avoids the opacity that results when approval, monitoring, and 
evaluation documents are not clearly and fully displayed on CMS or state Medicaid websites. All demonstrations should be subject to formal external, expert peer review, with reviews also available online. This would enable key stakeholders to comment on the adequacy of study design and to monitor harms to participants.

This approach is consistent with research ethics standards and with regulations that guide Medicaid demonstration program monitoring. Peer review and transparent evaluation also are consistent with academic norms and help to substantially reduce the chances of poor study designs without pre-defined endpoints, evaluations with limited validity, and undisclosed harms.

Current evidence suggests that skepticism of work requirements and personal responsibility policies is justified. To the extent that CMS permits these policies and that they survive legal challenges, states should implement them with great care and unambiguously prioritize protecting health over political goals. Promoting health is, after all, the goal of Medicaid. Otherwise, waivers look like little more than a tool for ideological social welfare cuts based on arbitrary determinations of who is deserving or undeserving of receiving the benefits that programs like Medicaid provide.

${ }^{1}$ Gurley-Calvez T, Kenney GM, Simon K, Wissoker D. Medicaid Reform and Emergency Room Visits: Evidence from West Virginia's Medicaid Redesign. Fairfax, VA: National Center for Policy Analysis. Retrieved from http://mercatus. org/sites/default/files/Medicaid-ReformEmergency-Room-Visits-Working-Paper_0. pdf. 2012 Sep

${ }^{2}$ Sommers BD, Gawande AA, Baicker K. Health insurance coverage and health - what the recent evidence tells us. New England Journal of Medicine. 2017 Aug 10;368(15): 377:586-593 3. Gangopadhyaya, A, Kenney, GM. Who Could Be Affected by Kentucky’s Medicaid Work Requirements, and What Do We Know about Them? Urban Institute, February 2018, Available at:

https://www.urban.org/sites/default/files/publication/96576/2018.02.15 ky_medicaid_numbers_f inalized 0.pdf (Accessed Feb 27, 2018)

${ }^{4}$ Bagley N. Are Medicaid Work Requirements Legal?. JAMA. 2018 Jan 30. 
${ }^{5}$ Rosenbaum, S. Experimenting on the Health of the Poor: Inside Stewart v. Azar. Health Affairs Blog. February 5, 2018, Available at:

https://www.healthaffairs.org/do/10.1377/hblog20180204.524941/full/

6 Bevin, MG Executive Order. Relating to Medicaid expansion. Available at:

http://apps.sos.ky.gov/Executive/Journal/execjournalimages/2018-MISC-2018-0040-253682.pdf (accessed Jan 29, 2018) 